\title{
Article \\ Undiagnosed Hypertension in a Workplace: The Case of a Logistics Company in Gauteng, South Africa
}

\author{
Morongwa Bokaba, Perpetua Modjadji * and Kebogile Elizabeth Mokwena (D) \\ Department of Public Health, School of Health Care Sciences, Sefako Makgatho Health Sciences University, \\ P.O. Box 215, Ga-Rankuwa MEDUNSA, Pretoria 0204, South Africa; Morongs28@gmail.com (M.B.); \\ kebogile.mokwena@smu.ac.za (K.E.M.) \\ * Correspondence: Perpetua.modjadji@smu.ac.za; Tel.: +27-12-521-3664
}

check for updates

Citation: Bokaba, M.; Modjadji, P.; Mokwena, K.E. Undiagnosed Hypertension in a Workplace: The Case of a Logistics Company in Gauteng, South Africa. Healthcare 2021, 9, 964. https://doi.org/ $10.3390 /$ healthcare 9080964

Academic Editor: Pedram Sendi

Received: 21 June 2021

Accepted: 16 July 2021

Published: 30 July 2021

Publisher's Note: MDPI stays neutral with regard to jurisdictional claims in published maps and institutional affiliations.

Copyright: (c) 2021 by the authors. Licensee MDPI, Basel, Switzerland. This article is an open access article distributed under the terms and conditions of the Creative Commons Attribution (CC BY) license (https:// creativecommons.org/licenses/by/ $4.0 /)$.

\begin{abstract}
A large proportion of the population with hypertension remains undiagnosed, untreated, or inadequately treated, contributing to the rising burden of cardiovascular diseases in South Africa. A workplace may either mitigate or accentuate the risk factors for hypertension. A cross sectional study was conducted to determine the prevalence of undiagnosed hypertension and associated factors among 312 employees in a Logistics Company, South Africa. A modified, validated, selfadministered WHO STEPwise questionnaire was used to collect data on demography, lifestyle factors, anthropometry and blood pressure (BP). Hypertension was defined at BP $\geq 140 / 90 \mathrm{mmHg}$. Data was analysed using STATA 14 . Mean age of employees was $40 \pm 10$ years, with a $50 \%$ prevalence of undiagnosed hypertension. No significant association was observed between occupation and undiagnosed hypertension, except for high prevalence of undiagnosed hypertension among truck drivers and van assistants (43\%), and general workers (27\%), having higher odds of increased waistto-height ratio. Hypertension was associated with age (OR $=2.3,95 \% \mathrm{CI} ; 1.21-4.27)$, alcohol use (AOR = 1.8, 95\%CI; 1.05-2.93), waist circumference (AOR = 2.3, 95\%CI; 1.29-4.07) and waist-to-heightratio $(\mathrm{AOR}=3.7,95 \% \mathrm{CI} ; 1.85-7.30)$. Improved and effective workplace health programs and policies are necessary for management of undiagnosed hypertension among employees. Longitudinal studies on mediation of occupation in association of demographic and lifestyle factors with hypertension in workplaces are needed.
\end{abstract}

Keywords: undiagnosed hypertension; risk factors; workplace; employees; logistic company; South Africa

\section{Introduction}

The burden of hypertension has shifted from high-income countries (HICs) to lowand middle-income countries (LMICs), including sub-Saharan Africa (SSA) [1]. For the past few decades, SSA has been experiencing an exponential increase in hypertension with an estimated prevalence of $5 \%$ to $50 \%$ [2-5]. However, a large proportion of the population with hypertension remains undiagnosed, untreated, or inadequately treated, contributing to the rising burden of cardiovascular diseases (CVDs) in the region $[5,6]$. Failure to treat and control hypertension predisposes to higher risk of cardiovascular events, kidney diseases [7,8], stroke [9], metabolic syndrome, hypertensive retinopathy [10] and dementia [11].

South Africa has documented a health transition characterized by a quadruple burden of communicable, non-communicable diseases (NCDs), perinatal and maternal, and injuryrelated disorders, over a decade ago [12]. Ever since, the focus has been on NCDs emerging in both rural and urban areas, resulting in increasing pressure on acute and chronic healthcare services, as one of the major public health concerns [12]. The country continues to record a higher mortality rate for NCDs than those for HIV / AIDS and tuberculosis combined [13,14], with CVDs being the leading category of NCDs [15]. Local studies in South Africa continue to report higher prevalence of hypertension (21\% to 52\%), in line with 
the epidemiological transition and increasing burden of chronic diseases of lifestyle [16-20]. The South Africa National Health and Nutrition Examination Survey (SANHANES) has reported that among those with hypertension, $48.7 \%$ were unscreened, $23.1 \%$ were screened but undiagnosed, 5.8\% were diagnosed but untreated, $13.5 \%$ were treated but uncontrolled and $8.9 \%$ were controlled, suggesting that $91.1 \%$ of the hypertensive population has an unmet need for care [21].

The South African Medical Research Council (SAMRC) technical report on chronic diseases [22] has suggested a conceptual framework that links NCDs and risk factors, as well as risky behaviors. Four modifiable risky behaviors that NCDs are attributable to are tobacco smoking, unhealthy diet, physical inactivity and alcohol use [23,24]. These behaviors contribute to several risk factors, such as hypertension and obesity [22,25], which are associated with NCDs [22]. Additionally, work-related requirements play a role in the development and progression of hypertension, for example, long working hours [26], shift work [27], and psychosocial factors [28,29]. Studies in South Africa have reported that NCDs, unhealthy lifestyle factors, hypertension and stressors are prevalent among employees in workplaces [18,30-32]. Differences in the prevalence of hypertension by occupational groups have been reported internationally [33]. According to Centers for Disease Control and Prevention (2016), employees with NCDs risk factors, such as hypertension and high cholesterol, cost employers in terms of absenteeism, and lost productivity, than employees with one or none of these risk factors [34].

Workplace may either mitigate or accentuate risk factors for hypertension [35]. Work is also considered as a captive environment in which people can be contacted for recruitment and program implementation [36]. Limited use of the available in-house clinic observed among most employees in this particular Logistics Company, despite the adequate equipment to diagnose and treat hypertension, is alarming. This was apparent during a wellness day organized by the company, when half of the employees recorded high levels of blood pressure not to their knowledge. This could only imply that many of these employees are living with undiagnosed hypertension, which is progressively exposing them to future unfavorable health outcomes, if left untreated. In addition, absenteeism due to ill health has been observed to be high, which might affect the productivity of the company. Researchers have reported that, when logistics performs well, there is trade expansion, export diversification, ability to attract foreign direct investments, and economic growth [37]. Yet data on NCDs is scarce in various companies, including this Logistics Company.

In view of this, the study aimed to determine the prevalence of undiagnosed hypertension and associated risk factors among employees in a Logistics Company, in the Gauteng Province of South Africa. Holistic approach of NCD management at a workplace is strengthened by both employer and employee education and participation, targeting several approaches including risk management and advocating healthy lifestyles as part of a healthy workplace program [38]. The implications of this study may highlight a need for companies without wellness days and in-house clinics to emulate this Logistic Company, to improve the health of employees, especially in relation to NCDs. While this particular company re-strategize and improve workplace health programs and policies for a proper management of NCDs among its employees.

\section{Materials and Methods}

\subsection{Study Design and Setting}

A cross sectional quantitative study was conducted in a Logistics Company from August 2019 to April 2020. The company is situated in Midrand, a business hub of companies in the Gauteng Province of South Africa. According to BusinessTech, Gauteng was the leading financial nerve center and manufacturing hub of SSA, and currently contributes 35\% to South Africa's Gross Domestic Product [39]. The Logistics Company used in this study specializes as a frozen third-party logistics operation servicing the South African food industry. It is a bulk cold storage enterprise, transporting food in refrigerated primary transport to retailers, and has multi-temperature warehousing and distribution. 
In this Logistics Company, a wellness program is organized twice a year (at the beginning of the year, and during mid-year) to promote a healthy workforce, and to identify unhealthy lifestyles and health conditions which affect productivity and that help in reducing absenteeism. In addition, it provides employees with strategies to adopt in maintaining healthy behaviors. The company has an in-house clinic, which is commendable. This approach is in line with WHO recommendations of workplaces as healthy settings to promote health, including interventions for NCDs. It is also in accord with the WHO Global Plan of Action on Workers Health 2008-2017, which was adopted at the 60th World Health Assembly [40]. Research shows that the health status of employees directly influences their work behaviour, attendance and job performance. Hence, effective wellness strategies can help alleviate both absenteeism and presentism, and their related costs [41]. Considering a wellness program, an in-house clinic and several occupations with varied job descriptions and shifts, these characteristics warranted use of this company as a case study.

\subsection{Study Population, Sampling and Sample Size}

The total population of employees in this particular Logistics Company is 1650. A representative sample of 312 was obtained following application of the Rao software sample calculator [42], which took into consideration the total population size of 1650 employees, a $5 \%$ margin of error and $95 \%$ confidence. We used systematic random sampling to select participants from a headcounts list, and to confirm participants as employees of the company, containing the names of all employees, provided by the company's human resource office.

The study considered 1598 floor employees and 46 managers and supervisors, making up a population of 1644 . The study excluded the six $(n=6)$ executive and human resources personnel, operating from the head office situated outside Gauteng, South Africa. During recruitment, employees who had previously been diagnosed with hypertension/chronic diseases, and were on medication at the time of the study, were excluded from the study, as well as female employees who indicated that they were pregnant.

\subsection{Data Collection Instruments and Procedures}

A modified, validated, self-administered WHO STEPwise questionnaire was used for data collection [43]. The information collected included demographics on occupation (i.e., job description and working shifts), age, marital status and education level, as well as smoking and alcohol use, fruit, vegetables and salt consumption, physical activity, family history of hypertension, and physical measurements (i.e., blood pressure and anthropometry) (see Supplementary Material).

The questionnaire was first prepared in English and then translated into the commonest spoken local language, iSiZulu, and validated through content and face validity, and via a pilot study [44]. Independent translators who speak isiZulu as their mother tongue and are conversant with English completed forward and backward translations of the questionnaire. An expert committee approved the final version of the translated questionnaire [44]. To make sure that the translated items retained the same meaning as the original items, and to ensure that there was no confusion regarding the translated questionnaire, a pilot study was conducted to pre-test it and determine its feasibility [44] among 15 employees who did not partake in the main study.

Blood pressure was measured according to the South African Hypertensive Practice Guideline 2014 using an approved, calibrated and validated electronic device attached to an arm cuff. Three readings were taken at two-minute intervals in a quiet room, an initial reading was discarded and the remaining two readings were recorded to take the average. We predicted workplace hypertension as a systolic blood pressure (SBP) $\geq 140 \mathrm{mmHg}$ or a diastolic blood pressure (DBP) $\geq 90 \mathrm{mmHg}$, or both, and studied the overall prevalence [45].

Weights for employees were measured to the nearest $0.1 \mathrm{~kg}$ using a calibrated smart D-quip electronic scale, and heights to the nearest $0.1 \mathrm{~cm}$ using a stadiometer, according to the WHO [46]. Three measurements were taken and the average weight $(\mathrm{W})$ and height $(\mathrm{H})$ 
were recorded. Body mass index (BMI) was calculated as the weight in kilograms divided by the height in meters squared $\left(\mathrm{BMI}\left(\mathrm{kg} / \mathrm{m}^{2}\right)=\right.$ weight $(\mathrm{kg}) /$ height $\left.\left(\mathrm{m}^{2}\right)\right)$. Normal BMI is within 18.5 to $24.99 \mathrm{~kg} / \mathrm{m}^{2}$. Underweight is defined as BMI $<18.5 \mathrm{~kg} / \mathrm{m}^{2}$, overweight as BMI of 25 to $29.99 \mathrm{~kg} / \mathrm{m}^{2}$ and obesity as BMI $\geq 30 \mathrm{~kg} / \mathrm{m}^{2}$. Waist circumference (WC) and hip circumferences (HC) were measured using a non-stretchable plastic tape measure. Central obesity was defined as WC $\geq 94$ centimeters $(\mathrm{cm})$ for males and $\geq 80 \mathrm{~cm}$ for females. Abdominal obesity was defined at waist-to-hip ratio (WHR) more than 0.90 for males and 0.85 for females whilst waist-to-height ratio (WHtR) of 0.5 was used for both sexes $[47,48]$.

\subsection{Data Analysis}

Descriptive and inferential statistics were performed using STATA 14 (StataCorp. 2015, Stata Statistical Software: Release 14, College Station, TX, USA). The interactive effect of undiagnosed hypertension and occupation, as well as other demographics, overweight/obesity indicators and lifestyle variables, were performed using a Chi-square test/Fisher's exact test. Further relationships of undiagnosed hypertension and selected variables were made through univariate, and multivariate (i.e., independent of occupation) logistic regression analyses. The purposeful selection process began with a univariate analysis of each variable, and any variable having a significant univariate test at $p$-value $<0.2$ was selected as a candidate for the multivariate analysis. Adjusted odds ratios (AOR) with a 95\% confidence interval (CI) were generated and used to determine the independent strength of the relationship. Significance was considered at $p<0.05$.

\subsection{Ethical Consideration}

Ethical clearance was granted by the Sefako Makgatho Health Sciences University Research and Ethics Committee, South Africa (SMUREC/H/46/2019: PG). Further permission to conduct the study was obtained from the clinic manager of the Logistic Company, as the clinic is responsible and accountable for employee's health and the company requested that its permission be issued.

\section{Results}

\subsection{Characteristics of Employees}

Three hundred and twelve (312) employees participated in the study, and the response rate was $100 \%$. Employees were divided into two age groups; $<30$ years and $\geq 30$ years. Mean age for employees was $40 \pm 10$ years with a minimum age of 21 years and a maximum age of 68 years. Male employees (82\%) were more than females (18\%), and predominantly black $(91 \%)$. Over half $(167 ; 54 \%)$ were single while $45 \%(n=140)$ were married. Almost half of the employees had post matric education $(n=152(49 \%))$. Some employees smoked $(37 \%(n=114))$ and some were alcohol users $(38 \%(n=195))$. Salt intake was common among employees at $99 \%(n=309)$, while $97 \%$ reported consuming fruits and vegetables. Physical activeness was reported in $44 \%(n=138)$ of the employees, while $41 \%$ came from a family with a history of hypertension (Table 1 ).

The overall means for SBP and DBP were $138 \pm 14.6 \mathrm{mmHg}$ and $85 \pm 10.5 \mathrm{mmHg}$, respectively. In Table 2, both males (49\%) and females (53\%) had an almost similar prevalence of hypertension. Older employees were significantly hypertensive (49\%) compared to younger. Obesity by BMI was significantly higher among females than males (49\% vs. $23 \%)$, as was central obesity by WC (86\% vs. 37\%). However, WHR was higher among males than females (77\% vs. $24 \%$ ). The WHtR was significantly high risk among females (84\%) compared to males (68\%). Older employees were significantly hypertensive (49\%) compared to younger. The prevalence of abdominal obesity by WHtR was significantly high among employees aged $\geq 30$ years compared to those aged $<30$ years. 
Table 1. Selected demographic variables and lifestyle factors.

\begin{tabular}{|c|c|c|c|}
\hline Variables & Categories & Frequency & Percentages (\%) \\
\hline \multirow{2}{*}{ Age } & $<30$ years & 66 & 21 \\
\hline & $\geq 30$ years & 246 & 79 \\
\hline \multirow{2}{*}{ Gender } & Male & 255 & 82 \\
\hline & Female & 57 & 18 \\
\hline \multirow{4}{*}{ Race } & Asian & 8 & 3 \\
\hline & Black & 284 & 91 \\
\hline & Colored & 3 & 1 \\
\hline & White & 17 & 5 \\
\hline \multirow{3}{*}{ Marital status } & Ever married & 140 & 45 \\
\hline & Single & 167 & 54 \\
\hline & Divorced & 5 & 16 \\
\hline \multirow{4}{*}{ Level of education } & Primary school & 2 & 0.6 \\
\hline & Secondary school & 37 & 12 \\
\hline & Matric & 121 & 39 \\
\hline & Post matric & 152 & 49 \\
\hline \multirow{2}{*}{ Smoking } & No & 198 & 64 \\
\hline & yes & 114 & 37 \\
\hline \multirow{2}{*}{ Alcohol use } & No & 117 & 63 \\
\hline & Yes & 195 & 38 \\
\hline \multirow{2}{*}{ Salt intake } & No & 85 & 24 \\
\hline & Yes & 265 & 76 \\
\hline \multirow{2}{*}{ Fruits consumption } & No & 10 & 3 \\
\hline & Yes & 302 & 97 \\
\hline \multirow{2}{*}{ Vegetables consumption } & No & 8 & 3 \\
\hline & Yes & 304 & 97 \\
\hline \multirow{2}{*}{ Physical active } & No & 174 & 56 \\
\hline & Yes & 138 & 44 \\
\hline \multirow{2}{*}{$\begin{array}{l}\text { Diagnosed with } \\
\text { Diabetes }\end{array}$} & No & 292 & 94 \\
\hline & Yes & 20 & 6 \\
\hline \multirow{2}{*}{$\begin{array}{l}\text { Family history of } \\
\text { hypertension }\end{array}$} & No & 184 & 59 \\
\hline & Yes & 128 & 41 \\
\hline
\end{tabular}

\subsection{Occupation Profile}

Occupations of employees in this company ranged from managerial (group 1), administration (group 2), checker (group 3), cycle counter (group 4), general workers (group 5-including fork-lifters, reach truck drivers, pickers, mechanics and route tracker), and truck drivers and van assistants (group 6), and were grouped based on link to job description. Most of the employees were in group 6, truck drivers and van assistants $(18(38 \%))$, and group 5, general workers $(92(30 \%))$. The prevalence of hypertension was high among general workers (27\%) and truck drivers with van assistants (43\%). However, no significant association was observed between occupation and hypertension (Fisher's exact; $p=0.266$ ) (Table 3$)$. 
Table 2. Comparison of prevalence of hypertension and selected variables by gender and age.

\begin{tabular}{|c|c|c|c|c|c|c|c|}
\hline Variables & All & Females & Males & & $<30$ Years & $\geq 30$ Years & \\
\hline & $n(\%)$ & $n(\%)$ & $n(\%)$ & $p$-Value & $n(\%)$ & $n(\%)$ & $p$-Value \\
\hline \multicolumn{8}{|l|}{ Blood pressure } \\
\hline Non-hypertensive & $156(50)$ & $27(47)$ & $129(51)$ & \multirow{2}{*}{0.660} & $45(68)$ & $129(51)$ & \multirow{2}{*}{$0.001 *$} \\
\hline Hypertensive & $156(50)$ & $30(53)$ & $126(49)$ & & $21(32)$ & $126(49)$ & \\
\hline \multicolumn{8}{|l|}{$\mathrm{BMI}\left(\mathrm{kg} / \mathrm{m}^{2}\right)$} \\
\hline Underweight & $9(3)$ & $2(4)$ & $7(3)$ & \multirow{4}{*}{$0.001^{* *}$} & $2(3)$ & $7(3)$ & \multirow{4}{*}{$0.135^{* *}$} \\
\hline Normal & $97(31)$ & $13(23)$ & $84(33)$ & & $27(41)$ & $70(28)$ & \\
\hline Overweight & $120(39)$ & $14(25)$ & $106(42)$ & & $25(38)$ & $95(37)$ & \\
\hline Obese & $86(28)$ & $28(49)$ & $58(23)$ & & $12(18)$ & $74(30)$ & \\
\hline \multicolumn{8}{|l|}{ WC } \\
\hline Normal & $168(54)$ & $8(14)$ & $160(63)$ & \multirow{2}{*}{$\leq 0.0001 *$} & $42(64)$ & $126(51)$ & \multirow{2}{*}{0.072} \\
\hline Central obesity & $144(46)$ & $49(86)$ & $95(37)$ & & $24(36)$ & $120(45)$ & \\
\hline \multicolumn{8}{|l|}{ WHR } \\
\hline Normal & $206(66)$ & $13(23)$ & $193(76)$ & \multirow{2}{*}{$\leq 0.0001^{*}$} & $50(76)$ & $156(63)$ & \multirow{2}{*}{0.060} \\
\hline Abdominal obesity & $106(34)$ & $44(77)$ & $62(24)$ & & $16(24)$ & $90(37)$ & \\
\hline \multicolumn{8}{|l|}{ WHtR } \\
\hline Normal & $90(29)$ & $9(16)$ & $81(32)$ & \multirow{2}{*}{0.016 * } & $28(42)$ & $62(25)$ & \multirow{2}{*}{$0.006^{*}$} \\
\hline Abdominal obesity & $222(71)$ & $48(84)$ & $174(68)$ & & $38(58)$ & $184(75)$ & \\
\hline
\end{tabular}

*-indicates a significant association by Chi2, **-indicates significant association by Fisher's exact, BMI = body mass index, WC $=$ waist circumference, $\mathrm{WHR}=$ waist hip ratio, $\mathrm{WH} \mathrm{HR}=$ waist to height ratio.

\subsection{Factors Associated with Hypertension}

Table 4 shows comparison of demographic and hypertension status. Undiagnosed hypertension was associated with age, marital status, education, alcohol use and physical activity.

In the unadjusted model at a $p$-value cut-off point of $<0.20$, age $(\mathrm{R}=2.6,95 \mathrm{CI}$; 1.47-4.63), and marital status (married, $\mathrm{OR}=2.0,95 \% \mathrm{CI} ; 1.28-3.18$ ) were associated with hypertension. Hypertension was also associated with smoking (OR $=0.7,95 \% \mathrm{CI} ; 0.45-1.14$ ), alcohol use (OR $=1.7,95 \% \mathrm{CI} ; 1.06-2.68)$, and physical activity ( $\mathrm{OR}=0.5,95 \% \mathrm{CI} ; 0.34-0.84$ ). Hypertension was associated with anthropometry, BMI (overweight, $\mathrm{OR}=10.8,95 \% \mathrm{CI}$; 1.31-89.3), obesity (OR = 19.5, 95\%CI; 2.32-164.3), WC (OR = 4.2, 95\%CI; 2.66-6.89), WHR $(\mathrm{OR}=2.3,95 \% \mathrm{CI} ; 1.40-3.66)$ and WHtR [OR $=6.6,95 \% \mathrm{CI} ; 3.67-11.78]$. WHtR was associated with truck drivers and van assistants $(\mathrm{OR}=3.3,95 \% \mathrm{CI}$; 1.16-9.45) and general workers $(\mathrm{OR}=2.4,96 \% \mathrm{CI} ; 0.83-6.86)$. No association was observed between undiagnosed hypertension and occupation (results not shown).

A multivariate model was built using the covariates (i.e., occupation, marital status, smoking, alcohol use, physical activity, BMI (body mass index), and WHR) mentionedabove and results showed that the odds of having hypertension were 2.3 times higher for employees aged $\geq 30$ years ( $A O R=2.3,95 \% C I ; 1.21-4.27$ ). Alcohol use predisposed employees to hypertension almost twice as much as those who did not use alcohol. The odds of hypertension were 2.3 times higher for employees with $\mathrm{WC}$ above normal ( $\mathrm{AOR}=2.3$, $95 \% \mathrm{CI} ; 1.29-4.07)$ and those with a WHtR $\geq 0.5(\mathrm{AOR}=3.7,95 \% \mathrm{CI} ; 1.85-7.30)$ (Table 5). 
Table 3. Occupation profile of employees.

\begin{tabular}{|c|c|c|c|c|c|}
\hline $\begin{array}{l}\text { Groups of } \\
\text { Occupations }\end{array}$ & $n$ & $\begin{array}{l}\text { Hypertensive } \\
\quad n(\%)\end{array}$ & $\begin{array}{l}\text { Non Hypertensive } \\
n(\%)\end{array}$ & Working Shifts & Summarized Job Description \\
\hline Group 1 (Manager) & 17 & $9(16)$ & $8(5)$ & $\begin{array}{l}\text { Day shift: } \\
7 \text { a.m. to } 4: 30 \text { p.m. } \\
\text { Night shift: } \\
5 \text { p.m. to } 3 \text { a.m. }\end{array}$ & $\begin{array}{c}\text { Processing orders, Operating mechanical and IT systems, Liaising with transport companies, suppliers } \\
\text { and clients, etc. }\end{array}$ \\
\hline $\begin{array}{c}\text { Group } 2 \\
\text { (Administrator) }\end{array}$ & 41 & $22(14)$ & $19(12)$ & $\begin{array}{l}\text { Day shift: } \\
7 \text { a.m. to } 4: 30 \text { p.m. } \\
\text { Night shift: } \\
5 \text { p.m. to } 3 \text { a.m. }\end{array}$ & $\begin{array}{c}\text { Receiving, checking and scanning of all incoming stock and shipments, Responsible for coordinating } \\
\text { Exports shipments to suppliers, etc. }\end{array}$ \\
\hline Group 3 (Checker) & 32 & $12(8)$ & $20(13)$ & $\begin{array}{l}\text { Day shift: } \\
7 \text { a.m. to } 4: 30 \text { p.m. }\end{array}$ & $\begin{array}{l}\text { Checks, processes, and clears customers' orders for shipments, Keeps the warehouse and its environs } \\
\text { clean to ensure safety, Operates, cleans, and maintains all the equipment used in the warehouse, etc. }\end{array}$ \\
\hline Group 4 (Cycle counter) & 12 & $4(3)$ & $8(5)$ & $\begin{array}{l}\text { Morning shift: } \\
3 \text { a.m. to } 1 \text { p.m. }\end{array}$ & $\begin{array}{l}\text { Perform daily cycle counts, Monitoring and controlling inventory integrity, Maintain product } \\
\text { identification, location, and lot code accuracy, Open cartons, bundles, and other containers to count } \\
\text { items and / or weigh materials to determine quantity on hand, etc. }\end{array}$ \\
\hline $\begin{array}{l}\text { Group } 5 \text { (General } \\
\text { workers: including fork } \\
\text { lifters, reach truck } \\
\text { drivers, mechanics, } \\
\text { route tracker and } \\
\text { picker) Mechanic Route } \\
\text { tracker Picker }\end{array}$ & 92 & $42(27)$ & $50(32)$ & $\begin{array}{c}\text { Day shift: } \\
6 \text { a.m. to } 5 \text { p.m., or until the } \\
\text { delivery is done } \\
\text { Night shift: } \\
5 \text { p.m. to } 3 \text { a.m. } \\
\text { Day shift: } \\
7 \text { a.m. to } 4: 30 \text { p.m. } \\
\text { Day shift: } \\
5 \text { a.m. to } 5 \text { p.m. } \\
\text { Night shift: } \\
5 \text { p.m. to } 5 \text { a.m. } \\
\text { Day shift: } \\
7 \text { a.m. to } 4: 30 \text { p.m. } \\
\text { Night shift: } \\
5 \text { p.m. to } 3 \text { a.m. }\end{array}$ & $\begin{array}{l}\text { Unload and upload material, Identify damages, Report shortages, Report quality deficiencies, Transport } \\
\text { raw materials to production workstations, Inspect machinery, Determine the need for repairs, Keep } \\
\text { updated records of inventory, Produce activity logs Checking and fixing trucks, machinery and forklifts } \\
\text { and reach trucks. } \\
\text { Dispatching of trucks in the morning, Monitoring Drivers and Van-assistant time keeping achieving } \\
\text { scheduled departure times for all routes, etc. } \\
\text { Manages pick ticket orders, Pulls warehouse items from the shelves based on number, size, color, } \\
\text { quantity, and quality requirements, Ensures that orders are accurate, Operates handling equipment } \\
\text { Shrink wraps products to pallets, Loads delivery vehicles, etc. }\end{array}$ \\
\hline $\begin{array}{l}\text { Group } 6 \\
\text { (Includes truck drivers } \\
\text { and van assistants) }\end{array}$ & 118 & $67(43)$ & $51(33)$ & $\begin{array}{l}\text { Day shift: } \\
6 \text { a.m. to } 5 \text { p.m., or until the } \\
\text { delivery is done } \\
\text { Night shift: } 5 \text { p.m. to } 3 \text { a.m. }\end{array}$ & $\begin{array}{l}\text { Inspect truck for defects and safe operating condition before, during and after trips, Drive truck to and } \\
\text { from designated destinations, etc. } \\
\text { Loading and unloading company products, Assisting drivers to find delivery locations, etc. }\end{array}$ \\
\hline
\end{tabular}


Table 4. Comparison of selected variables by hypertension status.

\begin{tabular}{|c|c|c|c|}
\hline Variables & Normal & Hypertensive & $p$-Values \\
\hline \multicolumn{4}{|l|}{ Age (years) } \\
\hline$<30$ & $45(29)$ & $21(13)$ & \multirow[b]{2}{*}{$0.001 *$} \\
\hline$\geq 30$ & $111(71)$ & $135(87)$ & \\
\hline \multicolumn{4}{|l|}{ Gender } \\
\hline Female & 27 (17) & $30(19)$ & \multirow[b]{2}{*}{0.660} \\
\hline Male & $129(83)$ & $126(81)$ & \\
\hline \multicolumn{4}{|l|}{ Marital status } \\
\hline Ever married & $57(37)$ & $83(53)$ & \multirow{3}{*}{$0.005^{* *}$} \\
\hline Single & $97(62)$ & $70(45)$ & \\
\hline Divorced & $2(1)$ & $3(2)$ & \\
\hline \multicolumn{4}{|l|}{ Level of education } \\
\hline Primary school & $1(0.6)$ & $1(0.6)$ & \multirow{4}{*}{$0.048^{* *}$} \\
\hline High school & $11(7)$ & $26(17)$ & \\
\hline Matric & $64(41)$ & $57(37)$ & \\
\hline Post matric & $80(51)$ & $72(46)$ & \\
\hline \multicolumn{4}{|l|}{ Smoking } \\
\hline No & $93(60)$ & $105(67)$ & \multirow[t]{2}{*}{0.158} \\
\hline Yes & $63(40)$ & $51(33)$ & \\
\hline \multicolumn{4}{|l|}{ BMI $\left(\mathrm{kg} / \mathrm{m}^{2}\right)$} \\
\hline Normal & $72(46)$ & $25(16)$ & \multirow{4}{*}{$\leq 0.0001^{* *}$} \\
\hline Underweight & $8(5)$ & $1(1)$ & \\
\hline Overweight & $51(33)$ & $69(44)$ & \\
\hline Obese & $25(16)$ & $61(39)$ & \\
\hline \multicolumn{4}{|l|}{ Alcohol use } \\
\hline No & $68(44)$ & $49(31)$ & \multirow{2}{*}{0.026 * } \\
\hline Yes & $88(56)$ & 107 (69) & \\
\hline \multicolumn{4}{|l|}{ Salt intake } \\
\hline No & $2(1)$ & $1(0.6)$ & \multirow[t]{2}{*}{1.000} \\
\hline Yes & $154(99)$ & $155(99.4)$ & \\
\hline \multicolumn{4}{|l|}{ Fruits consumption } \\
\hline No & $5(3)$ & $5(3)$ & \multirow[t]{2}{*}{1.000} \\
\hline Yes & $151(97)$ & $151(97)$ & \\
\hline \multicolumn{4}{|c|}{ Vegetables consumption } \\
\hline No & $4(3)$ & $4(3)$ & \multirow[t]{2}{*}{1.000} \\
\hline Yes & $152(97)$ & $152(97)$ & \\
\hline \multicolumn{4}{|l|}{ Physical activity } \\
\hline No & $75(48)$ & $99(63)$ & \multirow[t]{2}{*}{$0.006 *$} \\
\hline Yes & $81(52)$ & $57(37)$ & \\
\hline \multicolumn{4}{|c|}{ Diagnosed with Diabetes } \\
\hline No & $149(96)$ & $143(92)$ & \multirow[t]{2}{*}{0.165} \\
\hline Yes & $7(4)$ & $3(8)$ & \\
\hline \multicolumn{4}{|c|}{ Family history of hypertension } \\
\hline No & $93(60)$ & $91(58)$ & 0.818 \\
\hline Yes & $63(40)$ & $65(42)$ & \\
\hline
\end{tabular}


Table 5. Association of undiagnosed hypertension with covariates.

\begin{tabular}{|c|c|c|c|}
\hline Variables & AOR & $95 \% \mathrm{CI}$ & $p$-Value \\
\hline \multicolumn{4}{|l|}{ Undiagnosed } \\
\hline \multicolumn{4}{|l|}{ Hypertension } \\
\hline \multicolumn{4}{|l|}{ Age } \\
\hline$<30$ years & & 1 (Reference) & \\
\hline$\geq 30$ years & 2.3 & $1.21-4.27$ & $0.001 *$ \\
\hline \multicolumn{4}{|l|}{ Alcohol use } \\
\hline No & & 1 (Reference) & \\
\hline Yes & 1.8 & $1.05-2.93$ & 0.032 * \\
\hline \multicolumn{4}{|l|}{ WC } \\
\hline Normal & & 1 (Reference) & \\
\hline Abdominal obesity & 2.3 & $1.29-4.07$ & $0.005 *$ \\
\hline \multicolumn{4}{|l|}{ WHtR } \\
\hline Normal & & 1 (Reference) & \\
\hline Abdominal obesity & 3.7 & $1.85-7.30$ & $\leq 0.0001 *$ \\
\hline
\end{tabular}

\section{Discussion}

This study determined the prevalence of undiagnosed hypertension and associated risk factors among employees in a Logistics Company in South Africa. The overall prevalence of undiagnosed hypertension (50\%) recorded among employees in this study is high. This prevalence is almost similar to the $52 \%$ reported among a working population in South Africa [18], but higher compared to prevalence reported among workforces in other countries, such as Brazil (32\%) [49] and Nigeria (20.1\%) [50]. A South African study on hypertension among primary health care professional nurses has reported that $41 \%$ of the health care workers were unaware of their hypertensive status [18]. SANHANES has reported that, among those with hypertension in South Africa, $48.7 \%$ were not screened, while 23.1\% were screened but undiagnosed [21]. More concerning is undiagnosed, untreated, or inadequately treated hypertension, contributing to CVD mortality [5]. Numerous studies have provided evidence of the extent of the unmet need for hypertension services, including the proportion of those with hypertension who are unscreened, undiagnosed, untreated and uncontrolled in Africa, including South Africa [5,21,51,52].

Our data did not show a significant association between occupation and hypertension. The null finding was consistent with the majority of cross-sectional studies on blood pressure and work factors [28]. Significant associations with occupation are more likely to be observed in prospective and ambulatory BP studies $[28,35,53]$. However, the current study showed that truck drivers, van assistants (3.3 times) and general workers (2.7 times) were more likely to have increased WHtR (unadjusted), compared to employees in other occupations. WHtR is a better discriminator of CVDs than other anthropometric indicators, and it also indicates abdominal obesity [48,54]. In fact, the prevalence of hypertension among truck drivers and van assistants was $43 \%$, and $27 \%$ among general workers, which was higher than in other occupations, although not significant. A $45.2 \%$ prevalence of hypertension has been reported among truck drivers in a developing country (i.e., Brazil) [55], while a higher prevalence of 57\% was reported among taxi drivers [56] and 36\% among truck drivers [57] in South Africa. Truck drivers are associated with living and working conditions which increased risk for CVDs [58].

Most of the employees in the current study reported consuming fruits and vegetables, and more than half consumed salt and were physically inactive, while at least a quarter were current smokers and alcohol users. Hypertension is typically attributed to increased urbanization and population aging, along with behavioral risk factors, including tobacco and alcohol use, poor diet and physical inactivity [51]. The consumption of fruits and vegetables by almost all employees is inconsistent with findings on low consumption of fruits and vegetables reported in South Africa [32,59]. High salt consumption is also a 
key driver of hypertension, and there is strong evidence to indicate that South Africans consume up to two to three times the recommended daily allowance of five grams [60]. This is supported by the South Africa Demographic and Health Survey (SADHS), which has reported unhealthy eating in the population [61]. Two thirds of the workforce has been reported to be physically inactive in the current study, similar to other South African studies [32,61]. On the other hand, a quarter of employees in the current study reported current smoking, which is higher than previous research in the workforce (26\%) [32].

The current study recorded $38 \%$ alcohol use compared to 25\% [62] and 29\% [32] reported in industry in South Africa. Apparently, South Africa has one of the highest risky drinking patterns in the world [63], proven by several studies conducted in various population groups [64-66]. Amongst employees, rates of harmful alcohol use are high in several workforces in South Africa, such as the public, industrial and financial sectors [67]. Evidence has found that alcohol, and in particular heavy drinking, increases the risk of unemployment, and for those employed it increases absenteeism [68]. Our data showed that alcohol use predisposed employees to hypertension almost twice as much as those who did not use alcohol. The Prospective Urban and Rural Epidemiology (PURE) study in South Africa showed that employees self-reporting the consumption of alcohol had a $30 \%$ increased risk of developing hypertension [69]. This higher level of both hypertension and alcohol use may be explained by the threshold effect, where alcohol consumption exacerbates physiological damages that may lead to hypertension [70].

In this study, the odds of having hypertension were 2.3 times higher for employees aged $\geq 30$ years. This is similar to other studies that have reported the prevalence of hypertension increasing with age among the working population in developing and developed countries [71,72]. The association between age and hypertension has been documented in several African studies [51,73,74]. A possible mechanism of age-related hypertension entails the fact that age induces an increase in visceral fat and circulating leptin, which is associated with a significant increase in blood pressure [75]. Literature documents that metabolic syndrome promotes arterial stiffening and accelerates vascular aging and development of hypertension in humans [76-78]. This has also been suggested among health care workers as they age [18].

More than half of the employees in this study exceeded the risk thresholds for overweight/obesity. Obesity in the workforce is associated with difficulty performing work in confined spaces, decreased productivity, greater absenteeism, higher turnover and cost to company [61]. In addition, obesity has been associated with higher odds of hypertension among employees in developed [79] and developing countries [80,81]. The odds of hypertension were 2.3 times higher for employees with abdominal obesity (by WC) and 3.7 times higher for employees (by WHtR) in this study compared to employees with normal WC and WHtR. It is worth noting that overweight/obesity is one of the main public health concerns in South Africa among various population groups [82-85]. When obesity coexists with hypertension, it may further increase the development of CVDs [71]. The sympathetic nervous system over-activation, stimulation of the renin-angiotensin-aldosterone system, alterations in adipose-derived cytokines, insulin resistance, and structural and functional renal changes are implicated in obesity-hypertension complex [86].

These findings emphasize a need for intensified health promotion and NCD prevention, and Schouw et al. [32] have reported that the workplace is ideally suited for targeted interventions. Strategies to prevent hypertension could include intervention at the company level, promoting staff canteens, even in small and medium-sized companies, health promotion programs [36] and dietary modification interventions [87]. At the individual level, strategies could include interventions to control alcohol use and education about healthy eating [88]. The implementation of joint interventions would probably be more effective [87], particularly if targeting a well-defined population. As a result, the work environment directly shapes employee health and health behaviors, and acts as an accelerator or preventer of chronic disease [89]. 


\section{Limitations and Strengths}

It should be noted that this study has several limitations and strengths. A strength of this study is that it has scientifically quantified, and provided evidence on, undiagnosed hypertension and risk factors in the case of a Logistics Company in Gauteng, considering the presence of the in-house clinic and the two wellness programs taking place annually in the company, useful for further intervention. A second strength is that the survey measures were collected via self-reporting, resulting in very little missing data in the final analysis models, although the method is subject to recall errors. A third strength is that multilevel adjustment for covariates, which indicates the generalizability of the study results to companies with a similar environment and working conditions, is likely to be reliable. In terms of limitations, first, the data came from a cross-sectional survey in a homogenous working group at a Logistics Company used as a case study, which would not be representative of the entire working population in various companies in South Africa. Thus, the generalizability of current reported information to other regions should be limited. Second, the design of the cross-sectional study leaves open for interpretation the casual relationships between hypertension and their risk factors, which implies that our results must be interpreted with some caution. Third, many of the findings were self-reported such as tobacco and alcohol use, fruits, vegetables and salt consumption, which could lead to bias, in the sense that employees might have under-reported; hence, these variables should be interpreted with caution. In addition, fruits, vegetables and alcohol consumption, as well as physical activity, might have been under-estimated or under reported due to the social desirability of answering questions and the dichotomous questions used. Finally, our results lack biochemical markers, such as lipids, insulin and glucose, to accompany the physical measurements reported in this study, which would add value, and should be considered in the future. Prospective cohort studies are needed to determine the extent of the associations of demographic and lifestyle factors with hypertension mediated by occupation in various companies in the trading industry.

\section{Conclusions}

A high prevalence of undiagnosed hypertension was observed among the employees of this Logistics Company. Associations with hypertension ranged from factors such as age, marital status, education, alcohol use, physical activity, BMI (i.e., overweight and obesity), WC and WHtR (i.e., abdominal obesity) among employees. Our study findings contribute to the limited scientific literature on the association between undiagnosed hypertension and risk factors from the perspective of a logistics workplace. The findings also indicate that, among all job types, truck drivers and van assistants were more affected by undiagnosed hypertension and had a higher prevalence of abdominal obesity. A detailed subpopulation analysis to target high-risk occupations and an assessment of the interaction between significant risk factors are recommended. Future longitudinal studies are needed to determine the mediation of occupation, in its associations with demographic and lifestyle factors, with hypertension in various workplaces. Improved and effective workplace health programs and policies are necessary to contribute to proper management of NCDs, especially undiagnosed hypertension, among employees.

Supplementary Materials: The following is available online at https:/ /www.mdpi.com/article/10 .3390/healthcare9080964/s1. Questionnaire: Undiagnosed Hypertension in a Workplace: A Case of a Logistic Company in Gauteng, South Africa.

Author Contributions: Conceptualization, M.B. and P.M.; Formal analysis, P.M.; Investigation, M.B.; Methodology, M.B. and P.M.; Resources, M.B.; Software, P.M.; Supervision, P.M.; Writing—original draft, M.B. and P.M.; Writing - review \& editing, P.M. and K.E.M. All authors have read and agreed to the published version of the manuscript.

Funding: This research was self-funded. 
Institutional Review Board Statement: The study was conducted according to the guidelines of the Declaration of Helsinki, and approved by the Institutional Review Board (or Ethics Committee) of the Sefako Makgatho Health Sciences University, South Africa, (SMUREC/H/46/2019: PG, approved on 7 March 2019).

Informed Consent Statement: Participation was voluntary and the participants provided written informed consents.

Data Availability Statement: The dataset for participants generated and analysed during the current study is available from the corresponding author upon reasonable request.

Acknowledgments: The author would like to thank the management of a company for allowing the in-house clinic to grant us the permission to conduct the study. We are also grateful to the participants for their cooperation to participate in the study.

Conflicts of Interest: The authors declare no conflict of interest.

\section{References}

1. Zhou, B.; Bentham, J.; Di Cesare, M.; Bixby, H.; Danaei, G.; Cowan, M.J.; Paciorek, C.J.; Singh, G.; Hajifathalian, K.; Bennett, J.E. Worldwide trends in blood pressure from 1975 to 2015: A pooled analysis of 1479 population-based measurement studies with $19 \cdot 1$ million participants. Lancet 2017, 389, 37-55. [CrossRef]

2. Dalal, S.; Beunza, J.J.; Volmink, J.; Adebamowo, C.; Bajunirwe, F.; Njelekela, M.; Mozaffarian, D.; Fawzi, W.; Willett, W.; Adami, H.-O.; et al. Non-communicable diseases in sub-Saharan Africa: What we know now. Int. J. Epidemiol. 2011, 40, 885-901. [CrossRef]

3. De Ramirez, S.S.; Enquobahrie, D.A.; Nyadzi, G.; Mjungu, D.; Magombo, F.; Ramirez, M.; Sachs, S.E.; Willett, W. Prevalence and correlates of hypertension: A cross-sectional study among rural populations in sub-Saharan Africa. J. Hum. Hypertens. 2010, 24, 786-795. [CrossRef]

4. Ogah, O.S.; Rayner, B.L. Recent advances in hypertension in sub-Saharan Africa. Heart 2013, 99, 1390-1397. [CrossRef] [PubMed]

5. Ataklte, F.; Erqou, S.; Kaptoge, S.; Taye, B.; Echouffo-Tcheugui, J.B.; Kengne, A.P. Burden of undiagnosed hypertension in sub-saharan Africa: A systematic review and meta-analysis. Hypertension 2015, 65, 291-298. [CrossRef]

6. Maimela, E.; Van Geertruyden, J.P.; Alberts, M.; Modjadji, S.E.; Meulemans, H.; Fraeyman, J.; Bastiaens, H. The perceptions and perspectives of patients and health care providers on chronic diseases management in rural South Africa: A qualitative study. BMC Health Serv. Res. 2015, 15, 143. [CrossRef] [PubMed]

7. Faselis, C.; Doumas, M.; Papademetriou, V. Common secondary causes of resistant hypertension and rational for treatment. Int. J. Hypertens. 2011, 2011, 236239. [CrossRef] [PubMed]

8. Foëx, P.; Sear, J. Hypertension: Pathophysiology and treatment. Contin. Educ. Anaesth. Crit. Care Pain 2004, 4, 71-75. [CrossRef]

9. Wajngarten, M.; Silva, G.S. Hypertension and stroke: Update on treatment. Eur. Cardiol. Rev. 2019, 14, 111. [CrossRef]

10. Bhargava, M.; Ikram, M.; Wong, T.Y. How does hypertension affect your eyes? J. Hum. Hypertens. 2012, 26, 71-83. [CrossRef]

11. Obisesan, T.O. Hypertension and cognitive function. Clin. Geriatr. Med. 2009, 25, 259-288. [CrossRef]

12. Mayosi, B.M.; Flisher, A.J.; Lalloo, U.G.; Sitas, F.; Tollman, S.M.; Bradshaw, D. The burden of non-communicable diseases in South Africa. Lancet 2009, 374, 934-947. [CrossRef]

13. Nojilana, B.; Bradshaw, D.; Pillay-van Wyk, V.; Msemburi, W.; Somdyala, N.; Joubert, J.D.; Groenewald, P.; Laubscher, R.; Dorrington, R.E. Persistent burden from non-communicable diseases in South Africa needs strong action. S. Afr. Med. J. 2016, 106, 436-437. [CrossRef] [PubMed]

14. Pillay-van Wyk, V.; Msemburi, W.; Laubscher, R.; Dorrington, R.E.; Groenewald, P.; Glass, T.; Nojilana, B.; Joubert, J.D.; Matzopoulos, R.; Prinsloo, M. Mortality trends and differentials in South Africa from 1997 to 2012: Second National Burden of Disease Study. Lancet Glob. Health 2016, 4, e642-e653. [CrossRef]

15. Schutte, A.E. Urgency for South Africa to prioritise cardiovascular disease management. Lancet Glob. Health 2019, 7, e177-e178. [CrossRef]

16. Mphekgwana, P.M.; Malema, N.; Monyeki, K.D.; Mothiba, T.M.; Makgahlela, M.; Kgatla, N.; Makgato, I.; Sodi, T. Hypertension Prevalence and Determinants among Black South African Adults in Semi-Urban and Rural Areas. Int. J. Environ. Res. Public Health 2020, 17, 7463. [CrossRef]

17. Maimela, E.; Alberts, M.; Modjadji, S.E.P.; Choma, S.S.R.; Dikotope, S.A.; Ntuli, T.S.; Van Geertruyden, J.-P. The Prevalence and Determinants of Chronic Non-Communicable Disease Risk Factors amongst Adults in the Dikgale Health Demographic and Surveillance System (HDSS) Site, Limpopo Province of South Africa. PLoS ONE 2016, 11, e0147926. [CrossRef]

18. Monakali, S.; Goon, D.T.; Seekoe, E.; Owolabi, E.O. Prevalence, awareness, control and determinants of hypertension among primary health care professional nurses in Eastern Cape, South Africa. Afr. J. Prim. Health Care Fam. Med. 2018, 10, 1-5. [CrossRef]

19. Ntuli, S.T.; Maimela, E.; Alberts, M.; Choma, S.; Dikotope, S. Prevalence and associated risk factors of hypertension amongst adults in a rural community of Limpopo Province, South Africa. Afr. J. Prim. Health Care Fam. Med. 2015, 7, 847. [CrossRef]

20. Lloyd-Sherlock, P.; Beard, J.; Minicuci, N.; Ebrahim, S.; Chatterji, S. Hypertension among older adults in low- and middle-income countries: Prevalence, awareness and control. Int. J. Epidemiol. 2014, 43, 116-128. [CrossRef] 
21. Berry, K.M.; Parker, W.-a.; Mchiza, Z.J.; Sewpaul, R.; Labadarios, D.; Rosen, S.; Stokes, A. Quantifying unmet need for hypertension care in South Africa through a care cascade: Evidence from the SANHANES, 2011-2012. BMJ Glob. Health 2017, 2, e000348. [CrossRef]

22. Steyn, K.; Fourie, S.T.; Emple, N. (Eds.) Chronic Diseases of Lifestyle in South Africa: 1995-2005; South Africa Medical Research Council: Cape Town, South Africa, 2006. Available online: http:/ /www.mrc.ac.za/sites/default/ files/files/2016-07-14/cdl19952005.pdf (accessed on 15 May 2021).

23. Bradshaw, D.; Norman, R.; Lewin, S.; Joubert, J.; Schneider, M.; Nannan, N.; Groenewald, P.; Laubscher, R.; Matzopoulos, R.; Nojilana, B.; et al. Strengthening public health in South Africa: Building a stronger evidence base for improving the health of the nation. S. Afr. Med. J. 2007, 97, 643-651.

24. WHO. The Global Burden of Disease: 2004 Update; World Health Organization: Geneva, Switzerland, 2008. Available online: http://www.who.int/healthinfo/global_burden_disease/2004_report_update/en/index.html (accessed on 15 May 2021).

25. Ndinda, C.; Chilwane, D.; Mokomane, Z. Civil Society Activism in Accessing Healthcare in South Africa; South Africa Human Sciences Research Council: Cape Town, South Africa, 2013. Available online: www.hsrc.ac.za/en/research-data/ktree-doc/13805 (accessed on 13 May 2021).

26. Iwasaki, K.; Sasaki, T.; Oka, T.; Hisanaga, N. Effect of working hours on biological functions related to cardiovascular system among salesmen in a machinery manufacturing company. Ind. Health 1998, 36, 361-367. [CrossRef] [PubMed]

27. Suwazono, Y.; Dochi, M.; Sakata, K.; Okubo, Y.; Oishi, M.; Tanaka, K.; Kobayashi, E.; Nogawa, K. Shift work is a risk factor for increased blood pressure in Japanese men: A 14-year historical cohort study. Hypertension 2008, 52, 581-586. [CrossRef] [PubMed]

28. Gilbert-Ouimet, M.; Trudel, X.; Brisson, C.; Milot, A.; Vézina, M. Adverse effects of psychosocial work factors on blood pressure: Systematic review of studies on demand-control-support and effort-reward imbalance models. Scand. J. Work. Environ. Health 2014, 40, 109-132. [CrossRef] [PubMed]

29. Cuevas, A.G.; Williams, D.R.; Albert, M.A. Psychosocial Factors and Hypertension: A Review of the Literature. Cardiol. Clin. 2017, 35, 223-230. [CrossRef]

30. Patel, D.; Goetzel, R.Z.; Beckowski, M.; Milner, K.; Greyling, M.; da Silva, R.; Kolbe-Alexander, T.; Tabrizi, M.J.; Nossel, C. The Healthiest Company Index: A campaign to promote worksite wellness in South Africa. J. Occup. Environ. Med. 2013, 55, 172-178. [CrossRef]

31. Rajan, S.; Engelbrecht, A. A cross-sectional survey of burnout amongst doctors in a cohort of public sector emergency centres in Gauteng, South Africa. Afr. J. Emerg. Med. 2018, 8, 95-99. [CrossRef]

32. Schouw, D.; Mash, R.; Kolbe-Alexander, T. Risk factors for non-communicable diseases in the workforce at a commercial power plant in South Africa. Occup. Health S. Afr. 2018, 24, 145-152.

33. Schumann, B.; Seidler, A.; Kluttig, A.; Werdan, K.; Haerting, J.; Greiser, K.H. Association of occupation with prevalent hypertension in an elderly East German population: An exploratory cross-sectional analysis. Int. Arch. Occup. Environ. Health 2011, 84, 361-369. [CrossRef]

34. CDC. Worker Productivity | Blood Pressure Evaluation Measures; Division of Population Health, National Center for Chronic Disease Prevention and Health Promotion: Atlanta, GA, USA, 2016. Available online: https: / /www.cdc.gov/workplacehealthpromotion/ health-strategies/blood-pressure/evaluation-measures/worker-productivity.html (accessed on 15 May 2021).

35. Babu, G.R.; Jotheeswaran, A.T.; Mahapatra, T.; Mahapatra, S.; Kumar, A.S.; Detels, R.; Pearce, N. Is hypertension associated with job strain? A meta-analysis of observational studies. Occup. Environ. Med. 2014, 71, 220-227. [CrossRef]

36. Eng, J.Y.; Moy, F.M.; Bulgiba, A. Impact of a Workplace Health Promotion Program on Employees' Blood Pressure in a Public University. PLoS ONE 2016, 11, e0148307. [CrossRef]

37. Arvis, J.; Monic, A.L.; Ojala, L.; Shepherd, B.; Saslavsky, D. Connecting to Compete 2010: Trade Logistics in the Global Economy-The Logistics Performance Index and Its Indicators; World Bank: Washington, DC, USA, 2010. Available online: https: / / openknowledge. worldbank.org/handle/10986/24599 (accessed on 20 February 2021).

38. Pg Ismail, P.K.; Koh, D. Role of occupational health in managing non-communicable diseases in Brunei Darussalam. Glob. Health Action 2014, 7, 25594. [CrossRef]

39. BusinessTech. Gauteng is Africa's 7th biggest economy. Africa Check, 19 November 2018. Available online: https://businesstech. co.za/news/business/285272/gauteng-is-africas-7th-biggest-economy/(accessed on 26 March 2020).

40. Bertazzi, P.A.; Colombi, A.; Spallanzani, A. Proposal for a Global Plan of Action on Workers' Health—2008-2017. Med. Lav. 2007, 98, 255-260. [PubMed]

41. Chenoweth, D. Wellness Strategiesto Improve Employee Health, Performance and the Bottom Line. SHRM Foundation Executive Briefing. 2011. Available online: https:/ / www.shrm.org/foundation/ourwork/initiatives/the-aging-workforce/Documents/ PromotingEmployeeWell-Being.pdf (accessed on 19 January 2019).

42. RaosoftwareCalulator. Available online: http://www.raosoft.com/samplesize.html (accessed on 22 January 2019 ).

43. WHO. STEPS: A Framework Forsurveillance. The WHO STEPwise Approach to Surveillance of Noncommunicable Diseases (STEPS); World Health Organization: Geneva, Switzerland, 2003. Available online: https://www.who.int/ncd_surveillance/en/steps_ framework_dec03.pdf (accessed on 10 January 2019).

44. Tsang, S.; Royse, C.F.; Terkawi, A.S. Guidelines for developing, translating, and validating a questionnaire in perioperative and pain medicine. Saudi J. Anaesth. 2017, 11, S80-S89. [CrossRef]

45. Harada, K.; Karube, Y.; Saruhara, H.; Takeda, K.; Kuwajima, I. Workplace Hypertension Is Associated with Obesity and Family History of Hypertension. Hypertens. Res. 2006, 29, 969-976. [CrossRef] [PubMed] 
46. WHO. Obesity: Preventing and Managing the Global Epidemic; World Health Organization Technical Report Series 894; World Health Organization: Geneva, Switzerland, 2000.

47. WHO. Physical Status: The Use and Interpretation of Anthropometry, Report of a WHO Expert Committee; WHO Technical Report Series 854; World Health Organization: Geneva, Switzerland, 1995.

48. Ashwell, M. Obesity risk: Importance of the waist-to-height ratio. Nurs. Stand. 2009, 23, 49-54. [CrossRef] [PubMed]

49. Figueiredo, A.E.P.L.; Urbanetto, J.D.S.; Magnago, T.S.B.D.S.; Poli-de-Figueiredo, C.E. Psychosocial stress and hypertension in nursing staff. Clin. Nurs. Stud. 2015. [CrossRef]

50. Owolabi, A.O.; Owolabi, M.O.; OlaOlorun, A.D.; Amole, I.O. Hypertension prevalence and awareness among a health workforce in Nigeria. Internet J. Med. Update 2015, 10, 10-19. [CrossRef]

51. Adeloye, D.; Basquill, C. Estimating the prevalence and awareness rates of hypertension in Africa: A systematic analysis. PLoS ONE 2014, 9, e104300. [CrossRef]

52. Thorogood, M.; Goudge, J.; Kabudula, C.W.; Limbani, F.; Roseleur, J.; Gómez-Olivé, F.X. Time to review policy on screening for, and managing, hypertension in South Africa: Evidence from primary care. PLoS ONE 2019, 14, e0208983. [CrossRef] [PubMed]

53. LaMontagne, A.D.; Keegel, T.; Louie, A.M.; Ostry, A.; Landsbergis, P.A. A systematic review of the job-stress intervention evaluation literature, 1990-2005. Int. J. Occup. Environ. Health 2007, 13, 268-280. [CrossRef] [PubMed]

54. Pasdar, Y.; Moradi, S.; Moludi, J.; Saiedi, S.; Moradinazar, M.; Hamzeh, B.; Jafarabadi, M.A.; Najafi, F. Waist-to-height ratio is a better discriminator of cardiovascular disease than other anthropometric indicators in Kurdish adults. Sci. Rep. 2020, 10, 16228. [CrossRef]

55. Sangaleti, C.T.; Trincaus, M.R.; Baratieri, T.; Zarowy, K.; Ladika, M.B.; Menon, M.U.; Miyahara, R.Y.; Raimondo, M.I.; Silveira, J.V.; Bortolotto, L.A.; et al. Prevalence of cardiovascular risk factors among truck drivers in the South of Brazil. BMC Public Health 2014, 14, 1063. [CrossRef]

56. Adedokun, A.O.; Goon, D.T.O.; Wolabi, E.M.; Adeniyi, O.V.; Ajayi, A.I. Driving to Better Health: Screening for Hypertension and Associated Factors Among Commercial Taxi Drivers in Buffalo City Metropolitan Municipality, South Africa. TOPHJ 2017, 10, 303-312. [CrossRef]

57. Lalla-Edward, S.T.; Fischer, A.E.; Venter, W.D.F.; Scheuermaier, K.; Meel, R.; Hankins, C.; Gomez, G.; Klipstein-Grobusch, K.; Draaijer, M.; Vos, A.G. Cross-sectional study of the health of southern African truck drivers. BMJ Open 2019, 9, e032025. [CrossRef]

58. Solomon, A.J.; Doucette, J.T.; Garland, E.; McGinn, T. Healthcare and the long haul: Long distance truck drivers-A medically underserved population. Am. J. Ind. Med. 2004, 46, 463-471. [CrossRef]

59. Peltzer, K.; Phaswana-Mafuya, N. Fruit and vegetable intake and associated factors in older adults in South Africa. Glob. Health Action 2012, 5, 1-8. [CrossRef]

60. Eksteen, G.; Mungal-Singh, V. Salt intake in South Africa: A current perspective. J. Endocrinol. Metab. Diabetes S. Afr. 2015, 20, 9-13. [CrossRef]

61. South Africa Department of Health. South Africa Demographic and Health Survey 2003; Department of Health: Pretoria, South Africa, 2007. Available online: https:// dhsprogram.com/pubs/pdf/FR206/FR206.pdf (accessed on 15 May 2021).

62. Wilson, D. Routine screening tests for alcoholism. S. Afr. Med. J. Suid-Afrik. Tydskr. Geneeskd. 1999, 89, 949-951.

63. Fieldgate, I.B.J.; Madinane, M.; Ebrahim, Y.; Soobyah, L.; Jordaan, J. Economic Impact of an Advertising Ban on Alcoholic Beverages; Econometrix (Pty) Ltd.: Johannesburg, South Africa, 2013; pp. 24-36.

64. Modjadji, P.; Pitso, M. Maternal Tobacco and Alcohol Use in Relation to Child Malnutrition in Gauteng, South Africa: A Retrospective Analysis. Children 2021, 8, 133. [CrossRef]

65. Mokwena, K.; Sindane, P. Cigarette smoking and alcohol intake among high school learners in Pretoria, South Africa. Psychol. Educ. 2020, 57, 531-536.

66. Pengpid, S.; Peltzer, K.; Skaal, L.; Van der Heever, H. Screening and brief interventions for hazardous and harmful alcohol use among hospital outpatients in South Africa: Results from a randomized controlled trial. BMC Public Health 2013, 13, 644. [CrossRef]

67. Harker Burnhams, N.; Dada, S.; Linda, B.; Myers, B.; Parry, C. The extent of problematic alcohol and other drug use within selected South African workplaces. S. Afr. Med. J. 2013, 103, 845-847. [CrossRef] [PubMed]

68. Anderson, P. Alcohol and the Workplace. Available online: https://www.euro.who.int/_data/assets/pdf_file/0009/191367/8 Alcohol-and-the-workplace.pdf (accessed on 22 February 2021).

69. Zatu, M.C.; Van Rooyen, J.M.; Kruger, A.; Schutte, A.E. Alcohol intake, hypertension development and mortality in black South Africans. Eur. J. Prev. Cardiol. 2016, 23, 308-315. [CrossRef]

70. Lip, G.Y.; Beevers, D.G. Alcohol, hypertension, coronary disease and stroke. Clin. Exp. Pharmacol. Physiol. 1995, 22, 189-194. [CrossRef]

71. Lin, Y.; Lai, X.; Chen, G.; Xu, Y.; Huang, B.; Chen, Z.; Zhu, S.; Yao, J.; Jiang, Q.; Huang, H. Prevalence and risk factors associated with prehypertension and hypertension in the Chinese She population. Kidney Blood Press. Res. 2012, 35, 305-313. [CrossRef]

72. Wang, Y.; Wang, Q.J. The prevalence of prehypertension and hypertension among US adults according to the new joint national committee guidelines: New challenges of the old problem. Arch. Intern. Med. 2004, 164, 2126-2134. [CrossRef]

73. Owolabi, E.O.; Ter Goon, D.; Adeniyi, O.V.; Seekoe, E. Social epidemiology of hypertension in Buffalo City Metropolitan Municipality (BCMM): Cross-sectional study of determinants of prevalence, awareness, treatment and control among South African adults. BMJ Open 2017, 7, e014349. [CrossRef]

74. Pires, J.E.; Sebastião, Y.V.; Langa, A.J.; Nery, S.V. Hypertension in Northern Angola: Prevalence, associated factors, awareness, treatment and control. BMC Public Health 2013, 13, 90. [CrossRef] [PubMed] 
75. Intapad, S.; Tull, F.L.; Brown, A.D.; Dasinger, J.H.; Ojeda, N.B.; Fahling, J.M.; Alexander, B.T. Renal denervation abolishes the age-dependent increase in blood pressure in female intrauterine growth-restricted rats at 12 months of age. Hypertension 2013, 61, 828-834. [CrossRef]

76. Ferreira, I.; Van De Laar, R.J.; Prins, M.H.; Twisk, J.W.; Stehouwer, C.D. Carotid stiffness in young adults: A life-course analysis of its early determinants: The Amsterdam Growth and Health Longitudinal Study. Hypertension 2012, 59, 54-61. [CrossRef]

77. Safar, M.E.; Thomas, F.; Blacher, J.; Nzietchueng, R.; Bureau, J.-M.; Pannier, B.; Benetos, A. Metabolic syndrome and age-related progression of aortic stiffness. J. Am. Coll. Cardiol. 2006, 47, 72-75. [CrossRef]

78. Sowers, J.R. Diabetes mellitus and vascular disease. Hypertension 2013, 61, 943-947. [CrossRef] [PubMed]

79. Scheerbaum, M.; Langenbach, C.; Scheerbaum, P.; Heidemann, F.; Rieß, H.C.; Heigel, H.; Debus, S.E.; Behrendt, C.-A. Prevalence of cardiovascular risk factors among 28,000 employees. Vasa 2017, 46, 203-210. [CrossRef] [PubMed]

80. Bosu, W.K. Epidemic of hypertension in Ghana: A systematic review. BMC Public Health 2010, 10, 418. [CrossRef]

81. Ofori, S.N.; Obosi, J. Prevalence of hypertension among office workers in a multi-national company in the Niger-Delta with the 2017 American College of Cardiology/American Heart Association Blood Pressure Guidelines. Prev. Med. Rep. 2019, 15, 100899. [CrossRef] [PubMed]

82. Choma, S.S.; Alberts, M.; Modjadji, S.E. Conflicting effects of BMI and waist circumference on iron status. J. Trace Elem. Med. Biol. 2015, 32, 73-78. [CrossRef]

83. Debeila, S.; Modjadji, P.; Madiba, S. High prevalence of overall overweight/obesity and abdominal obesity amongst adolescents: An emerging nutritional problem in rural high schools in Limpopo Province, South Africa. Afr. J. Prim. Health Care Fam. Med. 2021, 13, 2596. [CrossRef]

84. Mahlangu, K.; Modjadji, P.; Madiba, S. The Nutritional Status of Adult Antiretroviral Therapy Recipients with a Recent HIV Diagnosis; A Cross-Sectional Study in Primary Health Facilities in Gauteng, South Africa. Healthcare 2020, 8, 290. [CrossRef] [PubMed]

85. Modjadji, P. Socio-demographic Determinants of Overweight and Obesity Among Mothers of Primary School Children Living in a Rural Health and Demographic Surveillance System Site, South Africa. Open Public Health J. 2020, 13, 518-528. [CrossRef]

86. Shariq, O.A.; McKenzie, T.J. Obesity-related hypertension: A review of pathophysiology, management, and the role of metabolic surgery. Gland Surg. 2020, 9, 80-93. [CrossRef] [PubMed]

87. Geaney, F.; Kelly, C.; Greiner, B.A.; Harrington, J.M.; Perry, I.J.; Beirne, P. The effectiveness of workplace dietary modification interventions: A systematic review. Prev. Med. 2013, 57, 438-447. [CrossRef] [PubMed]

88. Groeneveld, I.F.; Proper, K.I.; van der Beek, A.J.; Hildebrandt, V.H.; van Mechelen, W. Short and long term effects of a lifestyle intervention for construction workers at risk for cardiovascular disease: A randomized controlled trial. BMC Public Health 2011, 11, 836. [CrossRef]

89. Sorensen, G.; Landsbergis, P.; Hammer, L.; Amick, B.C., 3rd; Linnan, L.; Yancey, A.; Welch, L.S.; Goetzel, R.Z.; Flannery, K.M.; Pratt, C.; et al. Preventing chronic disease in the workplace: A workshop report and recommendations. Am. J. Public Health 2011, 101 (Suppl. S1), S196-S207. [CrossRef] [PubMed] 